\title{
CD28 Positive
}

National Cancer Institute

\section{Source}

National Cancer Institute. CD28 Positive. NCI Thesaurus. Code C150465.

An indication that expression of CD28 has been detected in a sample. 